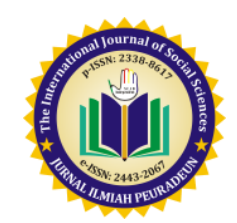

\title{
CHARACTER EDUCATION AS THE PRIMARY PURPOSE OF SCHOOLING FOR THE FUTURE
}

\author{
McRobert Lewis and Veronica Ponzio \\ Georgia State University, Atlanta, United States. \\ E-mail:lewis@gsu.edu.us
}

Received: Aug 3, 2015

Accepted: Nov 14, 2015

Published: May 28, 2016

Article Url: https://journal.scadindependent.org/index.php/jipeuradeun/article/view/92

\begin{abstract}
This analysis seeks to examine the history and development of moral/character education in America during the 20th century providing structure for the character education movement in today's educational context. The common denominator and key to character education for the future is community. The concept of community connects the three aforementioned themes and provides a roadmap for better implementation of character education. Careful consideration is given to the interaction and contributions of the school and society in terms of promoting and developing character education. Though there is generous support from politicians, educators, and parents, character education is still somewhat mired by its lack of scope. This examination proposes that current character education proponents can find new frameworks for implementation by observing the history of character education.
\end{abstract}

Keywords: Moral, Character, Education, Scholing, Century 20th 


\section{A. Introduction}

The development of moral character has been the subject of philosophical and psychological investigation since Aristotle theorized three levels of moral character development: an ethics of fear, an ethics of shame, an ethics of wisdom (Kraut, 2001). Philosophers, psychologists, and educators as diverse as John Locke, John Stuart Mill, Herbert Spencer, Emile Durkheim, and John Dewey, and as ancient as Confucius, Plato, and Aristotle have viewed the development of moral character as the primary purpose of schooling (Purpel \& Ryan, 1976). From the beginning of American public education in the 1600s until the first third of the 20 2 th century, our nation's educators, working closely with parents and the community, performed this moral-educational role with commitment (McClellan, 1992).

A few variants emerged out of social necessity including civic education, global education, multicultural studies, prudential education, social skills training, and values clarification. But as Heslep (1995) points out, these variants continued without moral education providing the "unifying context of principles" that is central to character education.

Moral education can be defined as "The conscious attempt to help others acquire the knowledge, skills, attitudes, and values that contribute to more personally satisfying and socially constructive lives" (Kirschenbaum, 1995: 14). Character education is defined as "Any school-initiated program, designed in cooperation with other community institutions, to shape directly and systematically the behavior of young people by influencing explicitly the no relativistic values believed to bring about that behavior" (Lockwood, 1997: 5-6). Character education is a primary concern in American schools today. Many feel that there is a "value crisis" operating in the lives of American youth (Kunjufu, 1993; Lickona, 1991). Character education places the task of educating students morally in the hands of public schools; despite the similarities between moral and character education, there are some subtle differences.

McDonnell (1991: 251) notes, "Character education is one of the most important, if not the most important, answer to our national crisis of character and it is absolutely essential to any truly effective reform movement". Bailey and Krejewski (1999: 35) assert, "Studies show that character education 
contributes to a decline in all forms of discipline problems, teen pregnancies, and adolescent use of marijuana, tobacco, and alcohol".

With this emphasis on recent connotations of character education, a logical course of action would be to examine past efforts in the area of moral education to provide context, support, and possible direction for today's efforts. This analysis seeks to examine the history and development of moral/character education in America during the $20^{\text {th }}$ century providing structure for the character education movement in today's educational context.

\section{B. Substantial Changes in Moral Education in the 20 $0^{\text {th }}$ Century}

Citizens need academic knowledge to function and prosper in this society. But a society that prepares its citizenry by emphasizing academics at the expense of ethical, social, and emotional development will not be healthy for long. As the founding constitution of the Phillips Exeter Academy put it in 1781: "Though goodness without knowledge is weak and feeble, yet knowledge without goodness is dangerous; both united form the noblest character, and lay the surest foundation of usefulness to mankind".

A substantial change in moral education in the 20th century was marking the approaches and attitudes related to moral education. The first half of the century was characterized by the familiar remnants of the nineteenth century; however, America's changing economy would demand more specialized course offerings, thereby lessening the role of moral education (Gutek, 1991; McClellan, 1999). By the middle of the century, moral education was somewhat infused with civics education in the Post-World War II/Cold War era. The 1960s and 1970s completely changed moral education. In the midst of Cultural Revolution, ethical dilemma, and numerous controversies, moral education took a back seat to individual rights, "personalism", and relativism (Lickona, 1991; McClellan, 1999). The 1980s and 1990s would witness a revival under the name of character education.

\section{Early 20th Century Character Education}

The early $20^{\text {th }}$ century brought new challenges to moral education. Due to increasing enrollments and a more industrial society, public school curricula had to be expanded. In addition, the modern society with its emphasis on 
productivity and the influence of technology allowed Americans more leisure time (McClellan, 1999). However, many felt that there was an overemphasis on leisure and society was not passing on "appropriate" values to the youth, especially during the 1920s. Thus, schools took a primary role in children's character formation (Field \& Nickell, 2000). Character education during this time period took the form of codes of conduct. Once city/state school officials developed suitable character traits, they then implemented various programs to pass them on to students (Field \& Nickell, 2000). McClellan (1999: 51) writes, "Educators expected moral codes to prompt teachers to attend to the development of character and to provide themes for instruction". In addition to curriculum, moral education took the form of after school clubs and interscholastic athletics (McClellan, 1999). As the 1920s drew to a close a significant research study would alter the course of character education.

\section{The Hartshorne and May Study}

This major study was aimed at determining the "effects of moral education, both secular and religious, on students' character-related behavior" between 1924 and 1929 (Mulkey, 1997: 35). This study was conducted by Hugh Hartshorne and Mark May with funds from the Institute of Social and Religious Research (Leming, 1997). Leming (1997: 33) writes, "The sample, drawn from private and public schools situated in eastern metropolitan areas of the United States, consisted of 10,850 students in grades five through eight. Hartshorne and May attempted to use representative samples combining various levels of socioeconomic status (SES), ethnic groups, types of communities, and intelligence levels". The study basically concluded, "character education programs, religious instruction, and moral training had no effect on the moral conduct of the students as measured in this study" (Mulkey, 1997: 35). However, Leming (1997: 35) notes the following:

May and Hartshorne themselves suggested that current practice simply needed to be improved somewhat by focusing less on direct methods of instruction such as lecture and exhortation and more on indirect methods of instruction such as the creation of a positive school climate and service-oriented activities for students. They did not seem to feel that the enterprise of character education should be abandoned. 
Though many critics used the results to slow character education efforts, character education remained strong throughout the 1930s (McClellan, 1999; Leming 1997). The direction of character education would change as American dealt with World War II and the Cold War.

\section{Post-World War II}

There was a reaffirmation of character education during the turbulent years of World War II. The war was viewed as a "moral contest in which the values of democracy and decency were arrayed against the forces of authoritarianism and evil, and classrooms were expected to play an important role in the battle" (McClellan, 1999: 71). The perils of war provided unity and direction for advocates of moral education. McClellan (1999: 71) notes, “The involvement of students in character building community activities gave comfort to moral educators of all persuasions and muddied the differences between them". In the aftermath of World War II, character education would gradually shift towards a civics focus with the encroaching Cold War.

The second half of the twentieth century would pose the most serious challenges to character education. "Both the Second World War and the early stages of the Cold War seemed to emphasize the importance of character, at least in the education of children and adolescents, and schools offered a rich variety of activities designed to promote moral and civic growth" (McClellan, 1999: 70). However, in this era, there was a shift from character education to civics education and even more curriculum expansion. Postwar public education would spawn innovations such as homerooms, additional student clubs, and citizenship or conduct grades (Leming, 1997). McClellan, (1999: 73) writes, "Without ever fully confronting the implications for moral education, postwar Americans began to demand that schools emphasize high-level academic and cognitive skills, often at the expense of the various forms of moral, civic, and social education that had been emphasized by earlier generations". The focus of character education was gradually changing. The change was attributed less to a distain for character education and more to shifts in societal and educational priorities (Leming, 1997; McClellan, 1999).

These shifts can mainly be attributed to the following:

a. A growing need for high-level technical skills. 
b. The emergence of a pervasive anticommunism.

c. Sharp distinctions between private and public spheres (McClellan, 1999: 73-74).

However, these shifts were a prelude to an era where character education itself would be under attack.

4. Conflicts of the 1960 s and 1970s

The 1960s and 1970s marked the temporary demise of character education. According to DeRoche and Williams (1998) several different factors caused confusion and resulted in little or no consensus on common values for public schools. McClellan (1999: 75) posits, "Faced with other knotty problems, most notable racial division, teachers and administrators were only too happy to flee from the task of moral education and return responsibility for character development to family and church". DeRoche and Williams (1998: 6) agree, noting, "There was a sense that everything was relative, situational, and personal, which was gradually moving the teachers and schools away from their traditional role as moral educators of the young". Lickona (1991) states that the 1960s and 1970s saw a rise in "personalism," individualism, and a new ethic of self-fulfillment. All of this ushered in the dismantling of what was character education in public schools. "With deep suspicions now sharpening racial, ethnic, and class divisions, Americans lost faith in their ability to find common ground...in the process they elevated cultural relativism to a primary social value" (McClellan, 1999: 75). "Many teachers seemed drained by students' and society's behaviors and focused less on moral matters and more on being dispensers of information and proponents of minimumcompetency tasks and tests" (DeRoche \& Williams, 1998: 8).

The 1960s and 1970s gave rise to a new attitude toward character education. This value-free approach was characterized in a movement called values clarification, pioneered by Louis Raths, Merrill Harmon, and Sidney Simon (Beach, 1992). "These approaches shared an emphasis upon reflection based on moral principles, teaching the whole child, and fostering intrinsic motivation and commitment. They commonly viewed autonomy as a distinguishing feature of true morality" (Vessels, 1998: 17). With values clarification, no teacher was to directly influence morality or dictate moral behavior. In reference to this movement, Beach (1992: 31) writes, “Indoctrination 
is the worst form of moral education, for it imposes upon the child some bag of rules that he or she may not understand or accept and may very likely resist. The most deadly pedagogical sin is moral imperialism". Though values clarification fit nicely into the educational and social climate of the day, it eventually drew criticism. Lickona (1991: 11) asserts, "It took the shallow moral relativism loose in the land and brought it into the schools...Values clarification discussions made no distinction between what you might want to do and what you ought to do". Beach (1992) notes the following criticisms of values clarification: (1) it makes matters of ethical right and wrong a matter of individual preference; (2) it lacks guidance in situations of moral collusion when a cherished value collides with another (e.g. Robbing Peter to pay Paul).

Eventually, values clarification fell by the wayside leaving schools to deal with the aftermath. According to Lickona (1991: 11), "In the end, values clarification made the mistake of treating kids like growups who only needed to clarify values that were already sound. It forgot that children, and a lot of adults who are still moral children, need a good deal of help in developing sound values in the first place". Character education in American schools was downplayed or virtually ignored until a revival in the 1980s and 1990s.

\section{The Return of Character Education}

The character education issue gained attention once again in the 1980s and 1990s. Vessels (1998: 5) writes, “Character education regained momentum during the 1980s and 1990s because many parents, educators, and other concerned citizens from various subcultures and regions of the country saw the need for prevention programs that would counter the tide of moral decline". According to many (see Beach, 1992; Canada, 2000; Kilpatrick, 1992; Lickona, 1991; McDonnell, 1999) character education is the remedy for this moral decline. The 1980s brought a rise in female-headed households, the collaboration of schools and business, and waves of reform fueled by a sense of academic urgency in K-12 schools. According to DeRoche and Williams (1998: 9) "The word character was reintroduced to the public, affirming that character formation, socialization, and the teaching of traditional American values were a proper role for schools". 
In the twenty-first century the character education debate continues. However, legislators, university professors, K-12 educators and people from all walks of life now are discussing the topic. We now exist somewhere between the culturally relativistic underpinnings of past decades and the urge for value consensus and culture commonality.

\section{Character Education and Implications for Schools}

Schools have always been in the business of character education. The word educate itself means to "supervise the mental or moral growth of." (Webster's Dictionary and Thesaurus, 1997). Schools traditionally have encouraged and promoted character education as part of their mission. Rather than being the schools' latest fad, character education is the schools' oldest mission (Schaeffer, 1999). Research into the hidden curriculum has revealed that the agenda of the schools is larger than the explicit list of courses, syllabi, and programs (Purpel, 1991). Schools teach more than academics - they teach values (Kunjufu, 1993). From early curricular materials such as the Horn Book and the New England Primer followed by the codes of conduct of the early twentieth century, to the contemporary character education programs of today, schools have always had a connection to a higher moral purpose in the development of students. Explicitly or implicitly schools remain at the forefront of debates and debacles in the effort to continue this ongoing mission of character education.

Given the tight connection between best practice instruction for academic expertise and for moral development, teachers are unwittingly engaged in character education when they structure lessons and organize classrooms in ways that optimally support student learning. The implication for teacher education is straightforward: adopt a best-practice approach to instruction for character education. Preserves reflective practice could address the pedagogical strategies that are correlated with student academic achievement, making apparent their implications for moral character education. Moreover teacher educators can help preserves teachers appreciate how and where moral values permeate classrooms and schools, and help them understand, too, that hiding values under the blanket of instructional best practice does not relieve them of their moral duty as educators or evade the fundamentally moral purpose of education. 
In summary, teachers need content knowledge about the links between caring classrooms, achievement and pro social character. Teachers need the pedagogical skills to pull it off; and they need the disposition to be committed to providing caring climates as a teaching practice. A second best practice is described: social and emotional skill development.

\section{Conclusion}

The common denominator and key to character education for the future is community. The concept of community connects the three aforementioned themes and provides a roadmap for better implementation of character education. In addition to schools there are other key players that need to be involved in the character education effort; these entities include businesses, universities and colleges, and other non-profit agencies. Hopefully, the result of collaborative character education efforts will be a kind of synergy that has the ability to combat negative behaviors, inspire and encourage students, and build strong caring communities.

History has the ability to guide our contemporary actions and provide a roadmap for future endeavors. The history of character education in American schools points to the fact that we all have a stake in the education of youth and the future depends on our genuine concern and collegial attitudes and not our criticism and contempt.

\section{Bibliography}

Bailey, E., \& Krajewski, B. (1999). Caring with passion: The "core" value. National Association of Secondary School Principals, 83(609), 33-39.

Beach, W. (1992). Ethical education in American public schools. Washington DC: National Education Association.

Canada, G. (1999). Raising better boys. Educational Leadership, 57 (4), 14-17.

DeRoche, E. F., \& Williams, M. M. (1998). Educating hearts and minds: A comprehensive character education framework. Thousand Oaks, California: Corwin Press.

Field, S. L., \& Nickell, P. (2000). 'The little red hen, soap sculpture, and analyzing magazines: Character education in the 1920s and '30s. The Educational Forum, 65(1), 73-79. 
Gutek, G. L. (1991). An historical introduction to American education (2nd ed.). Prospect Heights, IL: Waveland.

Kilpatrick, W. K. (1992). Why Johnny can't tell right from wrong. New York: Simon \& Schuster.

Kirshenbaum, H. (1995). 100 ways to enhance values and morality in school and youth settings. Needham Heights, MA: Allyn and Bacon.

Kunjufu, J. (1993). Hip-Hop vs. MAAT: A psycho/social analysis of values. Chicago: African American Images.

Leming, J. S. (1997). Research and practice in character education: A historical perspective. In A. Molnar (Ed.), The construction of children's character (pp. 31-44). Chicago: University of Illinois Press.

Lickona, T. (1991). Educating for character: How our schools can teach respect and responsibility. New York: Bantam Books.

Lockwood, A. T. (1997). Character education: Controversy and consensus. Thousand Oaks, CA: Corwin Press.

McClellan, E. (1999). Moral education in America: Schools and the shaping of character from colonial times to the present. New York: Teachers College Press.

McDonnell, S. N. (1999). Living up to a code of ethics: There is always room for improvement. Vital Speeches of the Day, 65(8), 249-251.

Mulkey, Y. J. (1997). The history of character education. Journal of Physical Education, Recreation, and Dance, 68, 35-37.

Purpel, D. E. (1991). Moral education: An idea whose time has gone. Clearing House, 64, 309-312.

Salami, S. (2015). Implementing Neuro Linguistic Programming (NLP) in Changing Students' Behavior: Research Done at Islamic Universities in Aceh. Jurnal Ilmiah Peuradeun, 3(2), 235-256.

Schaeffer, E. F. (1999). It's time for schools to implement character education. National Association of Secondary School Principals, 83(609), 1-8.

Vessels, G. G. (1998). Character and community development: A school planning and teacher training handbook. Westport, CT: Praeger.

Yusoff, M. Z. M., \& Hamzah, A. (2015). Direction of Moral Education Teacher To Enrich Character Education. Jurnal Ilmiah Peuradeun, 3(1), 119-132.

ZA, T. (2014). Islamic Studies dalam Pendekatan Multidisipliner (Suatu Kajian Gradual Menuju Paradigma Global). Jurnal Ilmiah Peuradeun, 2(2), 211-234. 